Letter

\title{
Temporal Anomalies in Burned Area Trends: Satellite Estimations of the Amazonian 2019 Fire Crisis
}

\author{
Joshua Lizundia-Loiola * ${ }^{\mathbb{D}}$, M. Lucrecia Pettinari ${ }^{\mathbb{D}}$ and Emilio Chuvieco $\mathbb{D}$ \\ Environmental Remote Sensing Research Group, Department of Geology, Geography and the Environment, \\ Universidad de Alcalá, Calle Colegios 2, 28801 Alcalá de Henares, Spain; mlucrecia.pettinari@uah.es (M.L.P.); \\ emilio.chuvieco@uah.es (E.C.) \\ * Correspondence: joshua.lizundia@uah.es
}

Received: 16 December 2019; Accepted: 30 December 2019; Published: 2 January 2020

\begin{abstract}
Tropical forests are known for hosting about half of the global biodiversity, and therefore are considered to be a fundamental part of the Earth System. However, in the last decades, the anthropogenic pressure over these areas has been continuously increasing, mostly linked to agricultural expansion. This has created great international concern, which has crossed the limits of national policies. A clear example was the last crisis suffered this year (2019) in the Amazon, and in general, in tropical South America (SA), due to the increasing fire activity in the region, which is strongly linked to deforestation and forest degradation. International media extensively informed the world about fire activity based upon active fire data, which provided quick but incomplete information about the actual fire-affected areas. This short paper compares fire occurrence estimations derived from the Moderate Resolution Imaging Spectroradiometer (MODIS) data of active fires and from burned area products for the first 10 months of 2019 in SA. Results show a significant increase in fire activity over the full-time series (2001-2018) in Bolivia, Paraguay and Venezuela, while Brazil shows a much higher BA than in 2018, but with values around the average burned area of the whole time series.
\end{abstract}

Keywords: fire disturbance; burned area; active fires; Amazon; South America; MODIS

\section{Introduction}

Satellite Earth data is an ideal tool to estimate the extent and impacts of different natural and human-caused hazards, as it provides a global and systematic observation of ground conditions at different spatial, spectral and temporal resolutions. After the launch of the first Landsat satellite in 1972, remote sensing images have been used for the different phases of fire management: before the fire, to estimate fire danger conditions; during the fire, to detect active fires and estimate fire behavior, and after the fire, to analyze fire effects and vegetation recovery [1].

Satellite images provide an objective estimation of actual fire occurrence, either by observing the thermal anomalies caused by active fires (AFs), or by detecting the changes in surface reflectance as a result of vegetation burning or scorching. The former approach is based on the high increment of ground emittance in the middle infrared (around $3.5 \mu \mathrm{m}$ ) caused by the high fire temperatures. This facilitates the detection of AF pixels as well as the energy they release (often termed fire radiative power (FRP)) [2]. On the other hand, the classification of the post-fire signal generally relies on the decrease in near-infrared reflectance as a result of burning, which is temporally more persistent than AFs. Yet the spectral contrast of burned and unburned signal is less sharp than the thermal anomaly, and burned pixels may be confused with other seasonal changes.

Characterization of fire occurrence from burned areas (BAs) is more precise than from AFs, as the latter only provides a sample of fire activity, which is the vegetation burning at the satellite overpass, 
while BA characterization includes the discrimination of the complete burned patches. Obviously, this implies that the classification of BAs is accurate enough, which is quite challenging, as other changes in reflectance conditions (agricultural practices, seasonal floods, clouds, cloud shadows, etc.) may affect the BA detection [3].

Tropical forests house over half of the known species on this Earth [4]. Their influence on Earth system processes is critical, via water transpiration and cloud formation, photosynthesis and respiration, and atmospheric circulation [5]. Fire is one of the main factors affecting forest degradation in tropical regions, and mostly in dry years where these regions become a net source of carbon [6]. The rainforest of the Amazonian basin is particularly sensitive to fire occurrence, as traditional practices of shifting cultivation have evolved in the last decades to more intensive crop production (sugar cane, soybeans, palm oil: [7]) and cattle farming [8], oriented towards the international market. Recently this situation has been enhanced by the US-China trade conflicts, which have implied a severe increase of Brazilian soy production [9]. Mining has also severe impacts in the Amazonia region, including oil exploration, as well as the extraction of gold and other metals [10].

The recent political change in Brazil was considered a potential factor of increasing deforestation in the country, as the new government was in favor of promoting the expansion of crops and ranging, while reducing the conservation policy of previous governments, and questioning the rights of indigenous preservation areas. All these policies have been shown to be closely related to deforestation and increasing fire occurrence [11,12]. These worries seemed to be confirmed when the first news of Amazonian fires emerged at the beginning of July 2019. The declarations of the French president Emmanuel Macron initiated a diplomatic crisis between France and Brazil, later aggravated by the inclusion of Brazilian Amazonian fires in the agenda of the G-7 meeting held in Biarritz (South of France) in August 2019.

This controversy fueled the interest of the media about fires in the region, and estimations on actual fire occurrence started to be published. The assumption was that fire activity was significantly higher than in ordinary years as a result of Brazilian President Jair Bolsonaro's policies [13]. Maps were published in newspapers and TVs showing fire activity in the whole continent based on AF detections mostly obtained by NASA and the Brazilian Space Research Institute (INPE). The main headlines indicated that these fires were considerably higher than usual: "There have been more than twice as many fires in Brazil this year as there were over the same period in 2013" [14], "Brazil's Amazon rainforest is burning at a record rate" [15] or "This year has seen the highest number of fires in Brazil since 2010" [16], although the latter article indicated that worse fire seasons occurred in the early 2000s, and also that other countries of the region were similarly being affected by severe fires.

Near-real-time information is obviously demanded by media, but these quick estimations of fire activity can only be based on AF detections, which—as mentioned above-are only a sample of the actual fire activity. Therefore, the most accurate estimations require classifying burned areas, which take longer to process. Unfortunately, when these more precise estimations are obtained, media interest has already declined, and therefore public controversies are not always very well informed.

This short paper explores the appraisal that was performed during the political crisis of 2019 based on AF information, and it compares the estimated numbers with trends derived from a global BA product. We analyzed whether the actual fire occurrence estimated by AF pixels is equivalent to that estimated from BAs, and whether the anomalies were significant versus previous years and a longer time series. Since fires affected not only Brazil, but other nations in the region, we have obtained BA information for all South American countries, and have calculated estimations of total BAs for 2019 (January to October, the most important months for fire occurrence), as well as anomalies of 2019 versus previous years and the full-time series derived from the MODIS sensor (2001-2018).

\section{Materials and Methods}

Burned area classification was based on MODIS 250m reflectance data [17], guided by thermal anomalies [18]. We used the same algorithm developed for the Fire Disturbance project (FireCCI) of 
the European Space Agency's Climate Change Initiative program (CCI). This algorithm is the most advanced version of a series of BA algorithms previously developed for the FireCCI project $[19,20]$. This algorithm is based on spatiotemporal clusters of AF pixels, which guide the detection of thresholds of near-infrared reflectance values to obtain burned and unburned pixels. Those thresholds vary in space and time, and therefore are well adapted to the wide variety of post-fire impacts upon reflectance changes [21]. This algorithm is the basis of the MODIS FireCCI51 product, which is publicly available (currently from 2001 to 2018) at the CCI data portal (http://cci.esa.int/data, last accessed December 2019) and the Copernicus Climate Change Service (https://cds.climate.copernicus.eu/, last accessed December 2019).

This product was validated using a statistically derived sample of 1200 Landsat pairs covering the period from 2003 to 2014 [21]. The FireCCI51 product improved the detection of small fires in comparison to other global BA products due to its higher spatial resolution, although a significant underestimation of small fires $(<100 \mathrm{ha})$ was observed, which are important in order to correctly estimate the actual BA, particularly in areas with a high agricultural activity [22-24]. However, currently, the moderate resolution global BA products are the best alternative to estimate BAs at the national, continental and global scale in a relatively short period after the fire event [3].

The objective was to obtain a quick evaluation of burned areas in South America, taking into account that most fire activity in that continent occurs between January and October (an average of $94 \%$ of all BA is burned in those months). We downloaded the Terra-MODIS MOD09GQ and MOD09GA products from Earth Data via direct download (https://search.earthdata.nasa.gov, last accessed November 2019) for the period encompassed between June 2018 and November 2019. About 29,000 daily images were downloaded distributed in 28 standard MODIS tiles of $1200 \times 1200 \mathrm{~km}$. The last 6 months of 2018 were processed in order to stabilize the algorithm results, and thus obtain correct estimates of 2019. After processing the algorithm, the date of detection (first date classified as burned) for each $250 \mathrm{~m}$ pixel was obtained. These results were later aggregated to obtain monthly and annual national statistics and also gridded maps at a 0.25 -degree resolution.

From the BA results, we computed the mean and the standard deviation of the full-time series (2001-2018) to obtain the standardized Z units ((value-mean)/standard deviation) for each year, considering the period January-October. These values were used to detect anomalies in BAs throughout the time series, including 2019.

\section{Results and Discussion}

The total BA in South America in the first 10 months of 2019 was $308,048 \mathrm{~km}^{2}$, around $70 \%$ more than in the same period of 2018 , but similar to the average BA of the time series $\left(292,562 \mathrm{~km}^{2}\right)$. Figure 1 shows the total BA detected by the FireCCI51 product in the six countries more intensively affected by fires in the continent. They account for a mean of $98.62 \%$ of the total BA in South America for the studied period (ranging from $96 \%$ to $99.5 \%$, depending on the year). In these countries, the total BA in 2019 was 1.71 times larger than in 2018, but only 1.05 larger than the average of the time series 2001-2018.

A similar trend was observed in the most affected countries. Brazil, for instance, had in 2019 a similar BA than the average of the 2001-2018 time-series (180,258 and $177,275 \mathrm{~km}^{2}$, respectively), but the BA was 2.2 times larger than the BA estimated for $2018\left(81,881 \mathrm{~km}^{2}\right)$. The relative impact of fires in the region was much worse in Bolivia than in Brazil. Bolivia tripled the BA of $2018(48,187$ versus $\left.15,448 \mathrm{~km}^{2}\right)$, and it also exceeded by $51 \%$ the average of the time series $\left(31,819 \mathrm{~km}^{2}\right) .2019$ was also clearly worse than 2018 in Venezuela (24\% more BAs, with $44 \%$ above time-series average), and in Paraguay ( $69 \%$ more BAs, but in this case very close to the average of the times series). Colombia and Argentina had less BA than in 2018 and this was also well below the average BA in the time series.

Figure 1 also shows the same information, but in this case based on the number of AFs, which was the information available to the media during the fire crisis. We observed similar tendencies to BA, although the differences with the fire activity of 2018 were less important than for the BAs. For instance, 
in the case of Brazil, the number of AF pixels increased by $62 \%$ over 2018 , but they were $7 \%$ lower than the time-series average (while the increases in BAs were estimated as $120 \%$ and $2 \%$, respectively). Similarly, in Bolivia, fire occurrence based on AFs provided lower estimations than for BAs, with an increase of $79 \%$ versus 2018 and $41 \%$ versus the time series (while the increases in BA were $212 \%$ and $51 \%$, respectively). In Venezuela, the AF detections increased by $26 \%$ compared to 2018 , and by $56 \%$ from the average time series, which in this case is similar to these BA estimations. This information is in line with the data reported by the BBC [16] during the fire crisis, although they were focused on Brazil and Bolivia and in the January-to-August period.

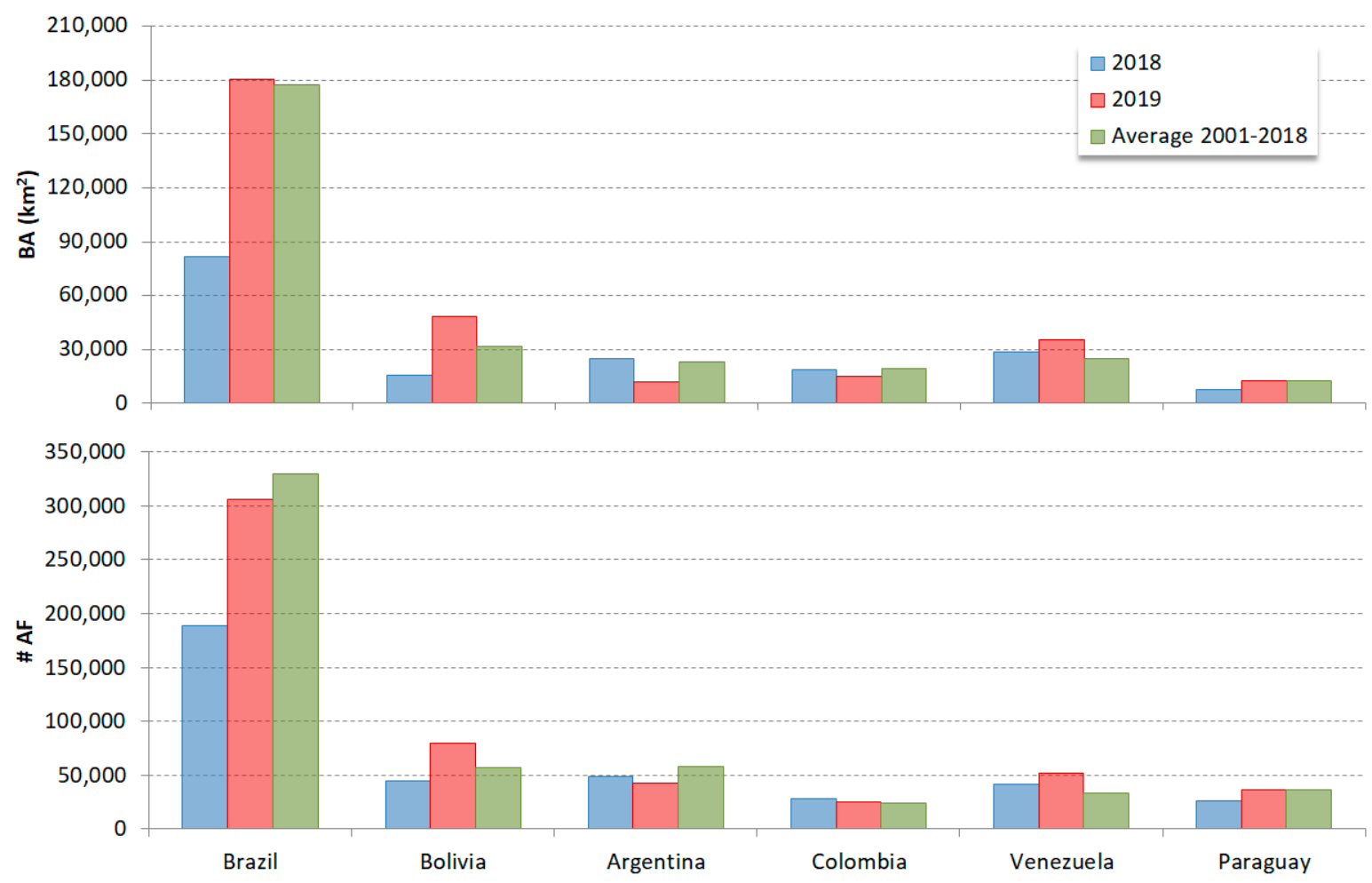

Figure 1. Country distribution of burned areas (BAs) and number of active fires (AFs) for 2018, 2019 and the average of the $2001-2018$ period.

In terms of yearly anomalies, Figure 2 shows the temporal trends of the full-time series for both BA and AF pixels between January and October. The trends are similar in the different countries but the actual values are generally higher for BA trends. Most of the countries have two years that can be clearly distinguished as the worst of the time series (i.e., having burned more than 2 standard deviations from the average BA, or having 2 standard deviations more AFs than the average), and in several cases those years affected more than one country. 2007 and 2010 were the worst years of the BA time series for Brazil, being the former also for Paraguay and Colombia and the latter for Bolivia. Argentina, Venezuela, and Paraguay were strongly affected in 2003, and Colombia also one year later. The worst year for Argentina was 2001. The trends showed by the AFs were quite similar, although some additional years with anomalies higher than 1 standard deviation were observed in Brazil (2005), Bolivia (2007), and Argentina (2008). The current year (2019) has only positive anomalies for Venezuela and Bolivia, both in terms of BAs and AFs, being one of the worst years of the time series for the mentioned countries, especially in the case of Venezuela. 

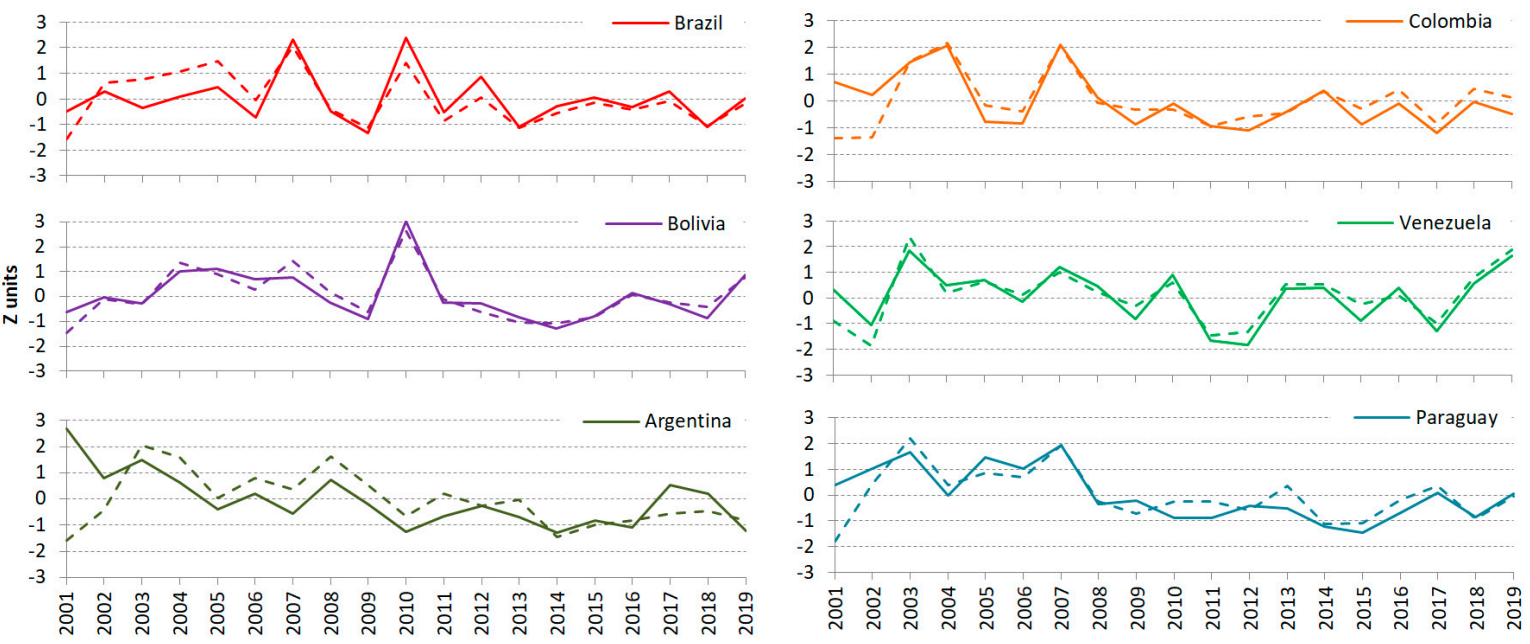

Figure 2. Country anomalies of BAs (solid line) and AFs (dotted line) for the 2001-2019 period (considering only from January to October).

In terms of the spatial variation of fire activity, Figure 3 shows the total BA in 2018 and 2019 for grids of $0.25^{0}$ degrees. The main differences between the two years are found in the Eastern and Southern regions of Venezuela, the border between Brazil, Bolivia and Paraguay, and the central region of Brazil, which all show increasing fire activity. Conversely, the central and northern regions of Argentina show lower fire activity. It is particularly interesting to observe three areas of significant fire increase from the previous year: the Pantanal area of Brazil (Rondonia and Matto Grosso) and Santa Cruz in Bolivia, affecting important conservation areas; the region of Goaiás, Pará, NE Matto Grosso and Tocantins in Brazil, and South Eastern (SE) Venezuela and Northern Roraima in Brazil.

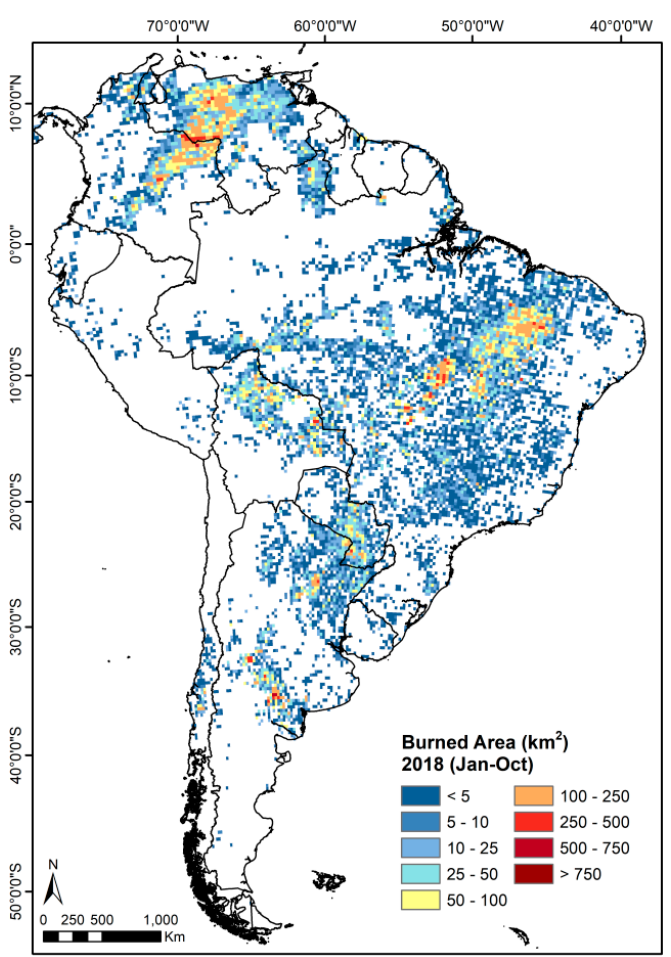

(a)

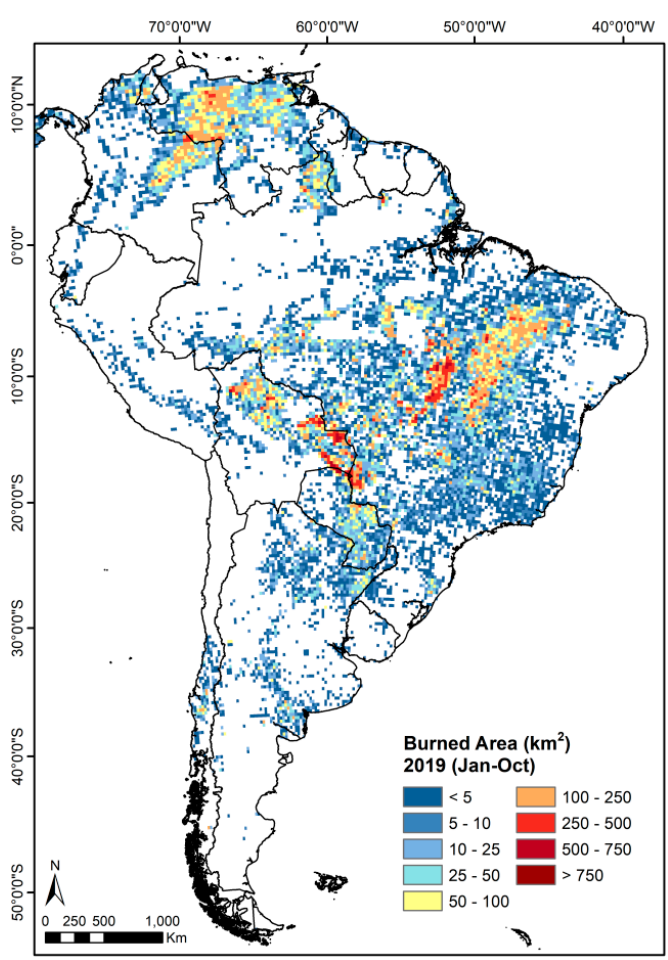

(b)

Figure 3. Spatial distribution of BAs in South America in 2018 (a) and 2019 (b). 
Finally, Figure 4a shows the spatial anomalies of the BAs in 2019. They were measured as standardized $Z$ units from the full-time series (2001-2018) for each 0.25-degree grid cell. The high-occurrence regions previously quoted are more clearly observed here. Very high positive anomalies are noticeable in the most affected regions of Eastern and SE Venezuela, Central and Western Brazil, Eastern Bolivia and Northern Paraguay. Anomalies are also observed in the central Andes of Peru, Ecuador and Colombia, as well as in the Amazonian regions of Colombia and Peru, particularly in the neighborhood of Pucallpa (Peru).

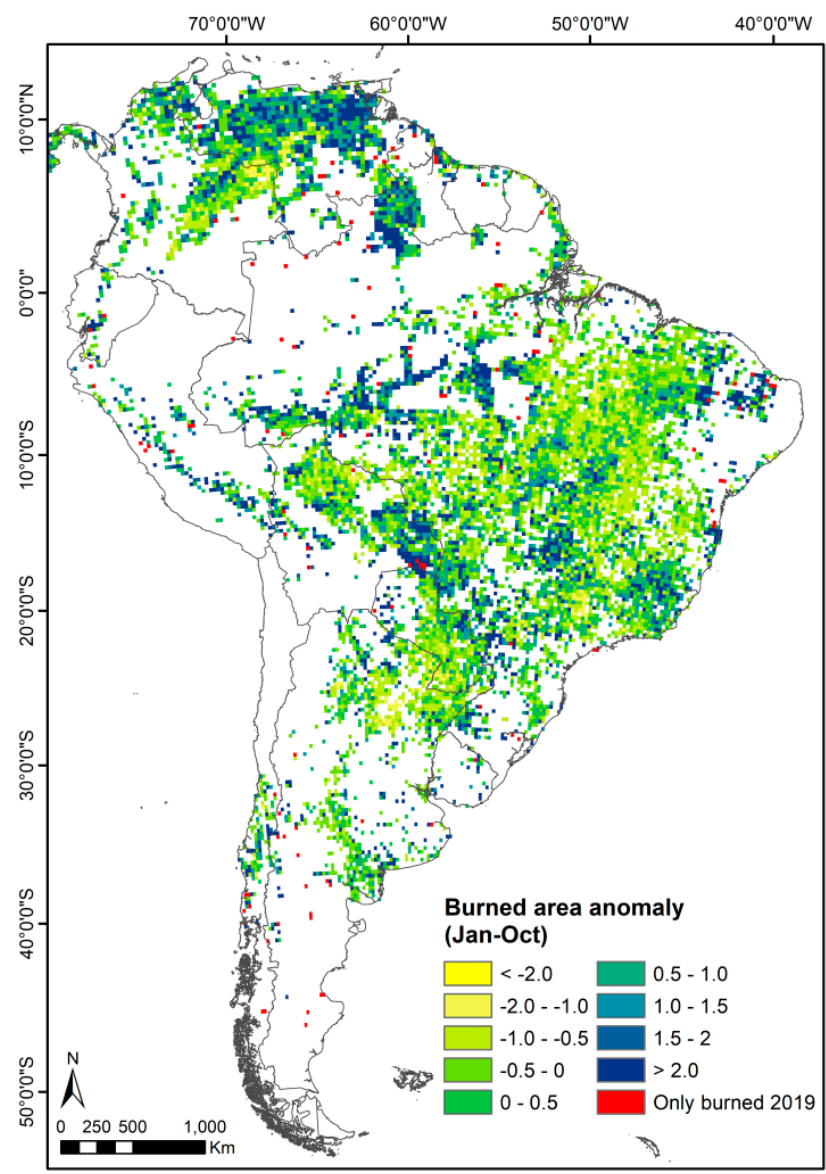

(a)

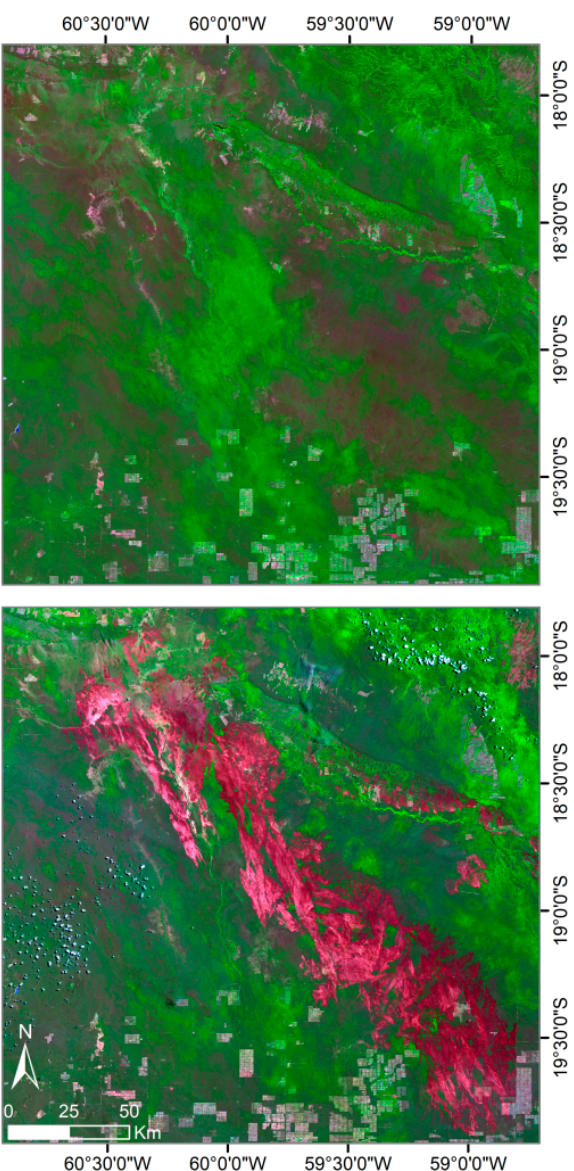

(b)

Figure 4. (a) Spatial anomalies of 2019 BAs in South America versus the time series of 2001-2018. Anomalies are computed as standardized $\mathrm{Z}$ units of BA for grid cells of $0.25^{0}$ degrees. (b) Sentinel-2B images of the area burned between the border of northern Paraguay and eastern Bolivia. Top: the pre-fire image of 09 July 2019; bottom: the post-fire image of 17 October 2019.

The spatial patterns of 2019 also show some grid cells (marked in red in Figure 4a) that had not previously burned during the time series. This implies that fire is being introduced into new areas, which in the case of evergreen tropical forest are very likely to be highly vulnerable to fire effects [25]. For example, the concentration of this new BA in the SE border of Bolivia, affecting severely the Chiquitano Dry Forest, is particularly striking (Figure 4b). Additional high anomaly cells were found in the interior of Brazil and in Northern Paraguay. This significant increase in fire activity could also be linked to governmental policies, with recent laws encouraging agricultural expansion [26,27].

\section{Conclusions}

The analysis of areas burned in 2019 in South America shows similar spatial trends to what was already observed with AFs in near-real-time, although BA estimations are generally higher. The main 
interest of BA products relies on quantifying the actual area affected by fires while refining the analysis of the temporal anomalies of fire activity showed by AF products. As a general summary, the high political controversy about new fires in the region should be more clearly applicable to Bolivia and Venezuela than to Brazil, which in 2019 had higher BAs than the previous year, but still around the average of the full-time series since the MODIS data is available. However, it is a major concern to identify areas in the Amazon region that were widely affected by fires in 2019 and had previously little or no fire occurrence, including regions in Brazil, Bolivia, Paraguay, Venezuela and Peru. Agricultural expansion has been identified by several studies as being behind the introduction of fire in these regions, but more detailed studies need to be carried out to detect the local drivers of fire.

Author Contributions: J.L.-L. processed the B.A. and A.F. information. J.L.-L. and M.L.P. created the graphs and maps. E.C., J.L.-L. and M.L.P. contributed to the analysis of the information and the writing of the manuscript. All authors have read and agreed to the published version of the manuscript.

Funding: This research has been financed by the European Space Agency (ESA) through the FireCCI project (Contract 4000126706/19/I-NB) and by the Spanish Ministry of Science, Innovation, and Universities through an FPU doctoral fellowship (FPU17/02438).

Conflicts of Interest: The authors declare no conflict of interest. The funders had no role in the design of the study; in the collection, analyses, or interpretation of data; in the writing of the manuscript, or in the decision to publish the results.

\section{References}

1. Chuvieco, E. Earth Observation of Wildland Fires in Mediterranean Ecosystems; Springer: Berlin/Heidelberg, Germany, 2009; p. 257.

2. Wooster, M.; Roberts, G.; Freeborn, P.; Xu, W.; Govaerts, Y.; Beeby, R.; He, J.; Lattanzio, A.; Fisher, D.; Mullen, R. LSA SAF Meteosat FRP products-Part 1: Algorithms, product. Atmos. Chem. Phys. 2015, 15, 13217-13239.

3. Chuvieco, E.; Mouillot, F.; van der Werf, G.R.; San Miguel, J.; Tanasse, M.; Koutsias, N.; García, M.; Yebra, M.; Padilla, M.; Gitas, I.; et al. Historical background and current developments for mapping burned area from satellite Earth observation. Remote Sens. Environ. 2019, 225, 45-64. [CrossRef]

4. Scheffers, B.R.; Joppa, L.N.; Pimm, S.L.; Laurance, W.F. What we know and don't know about Earth's missing biodiversity. Trends Ecol. Evolut. 2012, 27, 501-510. [CrossRef]

5. Lewis, S.L.; Edwards, D.P.; Galbraith, D. Increasing human dominance of tropical forests. Science 2015, 349, 827-832. [CrossRef]

6. Gatti, L.; Gloor, M.; Miller, J.; Doughty, C.; Malhi, Y.; Domingues, L.; Basso, L.; Martinewski, A.; Correia, C.; Borges, V. Drought sensitivity of Amazonian carbon balance revealed by atmospheric measurements. Nature 2014, 506, 76. [CrossRef]

7. Hansen, M.C.; Potapov, P.V.; Moore, R.; Hancher, M.; Turubanova, S.; Tyukavina, A.; Thau, D.; Stehman, S.; Goetz, S.; Loveland, T. High-resolution global maps of 21st-century forest cover change. Science 2013, 342, 850-853. [CrossRef] [PubMed]

8. Vale, P.; Gibbs, H.; Vale, R.; Christie, M.; Florence, E.; Munger, J.; Sabaini, D. The Expansion of Intensive Beef Farming to the Brazilian Amazon. Glob. Environ. Chang. 2019, 57, 101922. [CrossRef]

9. Fuchs, R.; Alexander, P.; Brown, C.; Cossar, F.; Henry, R.C.; Rounsevell, M. Why the US-China trade war spells disaster for the Amazon. Nature 2019, 567, 451-454. [CrossRef] [PubMed]

10. Arévalo, P.; Olofsson, P.; Woodcock, C.E. Continuous monitoring of land change activities and post-disturbance dynamics from Landsat time series: A test methodology for REDD+ reporting. Remote Sens. Environ. 2019, 111051. [CrossRef]

11. Nolte, C.; Agrawal, A.; Silvius, K.M.; Soares-Filho, B.S. Governance regime and location influence avoided deforestation success of protected areas in the Brazilian Amazon. Proc. Natl. Acad. Sci. USA 2013, 110, 4956-4961. [CrossRef] [PubMed]

12. Aragão, L.E.; Shimabukuro, Y.E. The incidence of fire in Amazonian forests with implications for REDD. Science 2010, 328, 1275-1278. [CrossRef]

13. Escobar, H. Amazon fires clearly linked to deforestation, scientists say. Science 2019, 365, 853. [CrossRef] 
14. Borger, J.; Watts, J. G7 Leaders Agree Plan to Help Amazon Countries Fight Wildfires. Available online: https://www.theguardian.com/world/2019/aug/26/g7-leaders-agree-plan-to-help-amazon-countriesfight-wildfires (accessed on 13 December 2019).

15. Yeung, J.; Alvarado, A. Brazil's Amazon Rainforest is Burning at a Record Rate, Research Center Says. Available online: https://edition.cnn.com/2019/08/21/americas/amazon-rainforest-fire-intl-hnk-trnd/index. html (accessed on 13 December 2019).

16. Rodgers, L.; Stylianou, N.; Guibourg, C.; Hills, M.; Bailey, D. The Amazon in Brazil is on Fire-How Bad is It? Available online: https://www.bbc.com/news/world-latin-america-49433767 (accessed on 13 December 2019).

17. Justice, C.O.; Townshend, J.R.G.; Vermote, E.F.; Masuoka, E.; Wolfe, R.E.; Saleous, N.; Roy, D.P.; Morisette, J.T. An overview of MODIS Land data processing and product status. Remote Sens. Environ. 2002, 83, 3-15. [CrossRef]

18. Giglio, L.; Schroeder, W.; Justice, C.O. The collection 6 MODIS active fire detection algorithm and fire products. Remote Sens. Environ. 2016, 178, 31-41. [CrossRef]

19. Chuvieco, E.; Lizundia-Loiola, J.; Pettinari, M.L.; Ramo, R.; Padilla, M.; Tansey, K.; Mouillot, F.; Laurent, P.; Storm, T.; Heil, A.; et al. Generation and analysis of a new global burned area product based on MODIS 250m reflectance bands and thermal anomalies. Earth Syst. Sci. Data 2018, 10, 2015-2031. [CrossRef]

20. Alonso-Canas, I.; Chuvieco, E. Global Burned Area Mapping from ENVISAT-MERIS data. Remote Sens. Environ. 2015, 163, 140-152. [CrossRef]

21. Lizundia-Loiola, J.; Otón, G.; Ramo, R.; Chuvieco, E. A spatio-temporal active-fire clustering approach for global burned area mapping at $250 \mathrm{~m}$ from MODIS data. Remote Sens. Environ. 2020, 236, 111493. [CrossRef]

22. Roteta, E.; Bastarrika, A.; Padilla, M.; Storm, T.; Chuvieco, E. Development of a Sentinel-2 burned area algorithm: Generation of a small fire database for sub-Saharan Africa. Remote Sens. Environ. 2019, 222, 1-17. [CrossRef]

23. Randerson, J.; Chen, Y.; Werf, G.; Rogers, B.; Morton, D. Global burned area and biomass burning emissions from small fires. J. Geophys. Res. Biogeosci. 2012, 117, 1-23. [CrossRef]

24. Cano-Crespo, A.; Oliveira, P.J.C.; Boit, A.; Cardoso, M.; Thonicke, K. Forest edge burning in the Brazilian Amazon promoted by escaping fires from managed pastures. J. Geophys. Res. Biogeosci. 2015, 120, 2095-2107. [CrossRef]

25. Cochrane, M.A.; Alencar, A.; Schulze, M.D.; Souza, C.M.; Nepstad, D.C.; Lefebvre, P.; Davidson, E.A. Positive feedbacks in the fire dynamic of closed canopy tropical forests. Science 1999, 284, 1832-1835. [CrossRef]

26. Romero-Muñoz, A.; Jansen, M.; Nuñez, A.M.; Toledo, M.; Almonacid, R.V.; Kuemmerle, T. Fires scorching Bolivia's Chiquitano forest. Science 2019, 366, 1082.

27. Pinna, M.; Da Silva Marques, J.V. Amazon Fires: Bolivia Experiences Worst Wildfires in Living Memory. Available online: https://www.euronews.com/2019/09/30/amazon-fires-bolivia-experiences-worst-wildfiresin-living-memory (accessed on 13 December 2019). 